J O U R N A L

$\mathrm{O} F \bullet \mathrm{B} A \mathrm{~L} T$ I C

$S$ C I E N C E

E DUCATION

ISSN 1648-3898
ISSNint/
ISS 2538-7138/Onine/

Abstract. Chemical eponyms possess important didactic and axiological potential that can be utilized for implementation of the principles of humanization and historicism manifested in national educational standards. This study focused on students' knowledge and views of eponyms in the

light of history of science. 22 general chemistry students of Belarusian State University, 131 students of general and

119 students of organic chemistry of University of Oregon, all different majors, were surveyed on their knowledge and views of eponyms using a 24-item online questionnaire. Mann-Whitney coefficients were calculated to establish significant differences and Pearson chi-square test was applied to find correlations. It was found that students' knowledge and views of eponyms are defined mostly by major: students majoring in teaching chemistry showed higher knowledge and expressed more positive views of eponyms than those majoring in non-teaching, non-chemistry and especially non-science. Other factors include students' learning experience and study intensiveness. While didactic potential of eponyms is utilized anyway, utilization of their axiological potential depends on instructor's willingness and mastery and should not be exaggerated as vehicles for the principles of humanization and historicism.

Keywords: chemical education, chemical eponym, named reaction, humanization, historicism, history of science.

Uladzimir Slabin
University of Oregon, USA
Vasili Krasitski
Belarusian State University,
Republic of Belarus

\section{FDR HUMANIZATION AND HISTORICISM: HOW WELL UNIVERSITY STUDENTS KNOW AND WHAT THEY THINK ABDUT CHEMICAL EPONYMS}

\section{Uladzimir Slabin, Vasili Krasitski}

\section{Introduction}

Eponymy is a word of Greek origin made up of epi - over, and noma - name. It means "giving name to something or naming after." Eponymy is understood as denominating a phenomenon, law, theory, principle, invention or procedure with the originator's name. In this way, the name of a discovery is derived from the name of the person who discovered or described it in the first instance (Fernandez-Cano \& Fernandez-Guerrero, 2003). Commonly known eponyms include Fahrenheit scale, Pythagorean theorem, Parkinson's disease, Petri dish, etc.

An alternative term is named (or name), e.g. named reactions, named laws, named effects. Even though this term is widely used for particular items, the generic two-word equivalent "named notion" is misleading and sometimes carries different connotation in contexts like: "These ideas that are acquired by abstraction, are named notions, to distinguish them from the simple ideas that they represent to the objects" (Ruiz, 2006).

On the one hand, scientific eponyms have been fairly well researched on and inventoried. Manuals and dictionaries hold eponyms in chemistry (Vatsuro \& Mishchenko, 1976; Hassner \& Stumer, 1994), medicine (Koehler, Bruyn, \& Pearce, 2001), zoology (Beolens, Watkins, \& Grayson, 2009), physics and mathematics (Ballentyne, Walker, \&Marton, 1959), social science (Lawson, 1984), psychology (Zusne, 1987), and eponyms in general (Manser, 1988; Beeching, 1989). They are available both as hard copies and as websites (Enersen, 1994). In medicine, e.g., an app for tablets and smartphones has been developed (Yee, n.d.) to bring descriptions of thousands of both common and obscure medical eponyms, and eventually biographies of "people who discovered a disease, pioneered a treatment, or invented a test, and later had their work named after them" (Paluzzi, 2010).

Meanwhile, active research on eponyms continues. They are discussed in many aspects, such as linguistic (Slabin, 1995; Stepkina, 2011), historical (Hoffman, 1987; Turnpenny \& Pigott, 2001; Kanne, Rohrmann, \& Lichtenstein, 2006), philosophical (Bayer, 1987) and even gender studies (Allchin, 2011). Numerous investigations focus on eponyms in the context of national history 
of science, e.g. Spanish (Fernandez-Cano et al., 2003) and Italian (Papeo \& Pulici, 2013), establishing or questioning priority in a discovery or an invention (Felts, 1999; Turnpenny \& Pigott, 2001; Drahl, 2010; Funk, 2013), ethical issues arising from using Nazi physician eponyms (Sala \& De Renzi, 2002; Woywodt, Matteson, \& Whitworth, 2007), etc.

Eponyms are also researched from pedagogical prospective. Addressing educational implications of eponyms in science education, Govindarajan and Rao (1993) mention anecdotal and historical merits of eponyms and argue: "Learning of eponyms in science education can significantly enlighten the motivated as well as the disinterested student to embark upon a diligent and productive endeavor in education, and to relate the knowledge to present day life and society" (p. 340).

Eponyms possess two pedagogical potentials - didactic and axiological. The former is obvious: students should study eponyms just because they are a part of the subject. Being a form of shorthand, they make professional communication easier because specialists quickly recall their content and understand the subject. Snieckus (2010) points out this asset: "For organic chemists, there is a direct cerebral cascade among name reaction-chemical structure mechanisms that, for many of us, continues to succeed in information retrieval without Googling" (p. 3). The Merck Index (1952, $6^{\text {th }}$ ed.) began including a section on named reactions, and since then dozens more books and websites containing chemical eponyms have sprung up.

The axiological potential of eponyms lies in introduction of values, the component that nowadays science and technology education overwhelmingly needs (Lamanauskas, 2015). Because every eponym can be unwrapped into a history of discovery, through eponyms instructor can convey important values to students. The axiological approach (Dvulichanskaya, 2011) puts up a principle of humanization in education, which implies that along with subject knowledge, educational tasks should include additional information on human activity in various aspects such as history and art. This approach holds for both secondary and higher education.

In national documents governing education, eponyms are usually not mentioned as such but they are present in the discourse of history and nature of science. The US National Science Education Standards (1996) emphasize the importance of history of science and individual scientists at all levels (K-4, K-8 and K-12) in content standard $\mathrm{G}$ (history and nature of science): "All students should develop understanding of science as a human endeavor... Many individuals have contributed to the traditions of science. Studying some of these individuals provides further understanding of scientific inquiry, science as a human endeavor, the nature of science, and the relationships between science and society" (p. 171). The US Next Generation Science Standards (2013) encourage "discussions involving the history of scientific and engineering ideas, of individual practitioners" contributions" because "...for many students, these aspects are the pathways that capture their interest in these fields and build their identities as engaged and capable learners of science and engineering" (p. xviii, Introduction).

Envisioning science as a human endeavor correlates with the aforementioned principle of humanization in the Republic of Belarus Concept of Chemistry as a Subject (2009) that "implies demonstrated relationship between chemical knowledge and human life" (p. 5). The principle of historicism "implies using history of chemical science as well as biographies of outstanding chemists in the school course of chemistry" (ibid., p. 7). The Republic of Belarus Standard of Chemistry as a Subject (2009) lists famous chemists (Lomonosov, Lavoisier, Dalton, Avogadro, Mendeleev, Arrhenius, Butlerov, Kekule) along with their discoveries. In fact, the Standard describes chemical eponyms without explicitly referring to them.

Since eponyms, with respect to their didactic and axiological potentials, are a part of history of science and its teaching is in line with humanization and historicism, whether explicitly manifested or implicitly present in the two countries' national educational standards, the following research goals were set:

- to estimate students' knowledge of eponyms and to identify factors that define this knowledge;

- to estimate students' views of eponyms and to identify factors that define these views;

- to study students' views of history of science as a background and a context the scientific eponyms are embedded in.

\section{Research Methodology}

Aiming at a description of the existing situation with chemical eponyms at universities of the two countries, identification of the factors that cause this situation, and eventually finding correlations between the causes and the effects, this research was combined descriptive, correlational, and causal-comparative. Consequently, it employed methods typical for these types of educational research. 


\section{Participants}

The participants were students of University of Oregon (Eugene, USA) and Belarusian State University (Minsk, Belarus). To get a more representative picture, it was decided to survey students taking: 1) regular and summer courses of 2) general and organic chemistry in 3) two different countries - USA and Belarus, total of five groups. Whereas regular course cycles in both countries last about 30 weeks in academic year, summer cycles last 12 weeks and are taught in an accelerated way. The last circumstance makes summer cycles popular among students of all years of study - science- and non-science majors, who choose chemistry to fill the requirement for a science class. Thus, bringing summer students made the sample more representative.

Table 1. The participants.

\begin{tabular}{|c|c|c|c|c|c|c|c|}
\hline \multirow{2}{*}{$\begin{array}{c}\text { Groups by } \\
\text { university and coursea }\end{array}$} & \multirow{2}{*}{$\begin{array}{l}\text { Time of survey } \\
\text { administration }\end{array}$} & \multicolumn{2}{|c|}{ Gender } & \multicolumn{4}{|c|}{ Major } \\
\hline & & Male & Female & Chemistry $^{b}$ & Science $^{c}$ & $\begin{array}{c}\text { Social } \\
\text { science }\end{array}$ & Total \\
\hline \multirow{2}{*}{$\begin{array}{l}\text { University of Oregon } \\
\text {-regular general chemistry }\end{array}$} & Jun 2014 & \multirow{2}{*}{24} & \multirow{2}{*}{63} & \multirow{2}{*}{6} & \multirow{2}{*}{78} & \multirow{2}{*}{3} & \multirow{2}{*}{87} \\
\hline & Sep 2015 & & & & & & \\
\hline -summer general chemistry & Sep 2014 & 20 & 24 & 8 & 32 & 4 & 44 \\
\hline - regular organic chemistry & Jun 2014 & 24 & 33 & - & 57 & - & 57 \\
\hline - summer organic chemistry & Aug 2014 & 17 & 45 & 2 & 58 & 2 & 62 \\
\hline $\begin{array}{l}\text { Belarusian State University } \\
\text { - general chemistry }\end{array}$ & May 2014 & 10 & 12 & $20 d$ & - & 2 & 22 \\
\hline \multicolumn{8}{|c|}{$\begin{array}{l}\text { Note. The listed majors actually included groups of majors. } \\
\text { aln subsequent tables and text, self-explanatory abbreviations are used: UO regular GenChem, UO summer GenChem, UO general } \\
\text { OrgChem, UO summer OrgChem, and BSU regular GenChem. } \\
{ }^{b} \text { Also Biochemistry. 'Biology, Environmental Studies, General Science, Geological Sciences, Human Physiology, and Physics. }{ }^{d} \text { Chemistry } \\
\text { Teaching and Chemistry Scientific/Industrial. }\end{array}$} \\
\hline
\end{tabular}

All the courses consisted of lectures, seminars, quizzes, and exams. There were no laboratory classes. The courses utilized textbooks with eponyms and sometimes related chemists'images - general (Silberberg, 2012) and organic chemistry (Bruice, 2014) for UO, general chemistry (Tretyakov, 2004) for BSU. No intervention to enhance students' views of eponyms was performed.

\section{Strategy and Procedure}

After the courses at participating university were over (2014 and 2015), a 27-item questionnaire (Slabin, 2014a) was administered among students of the five groups. The questionnaire was mounted on Qualtrics, a platform for online data collection. The questionnaire contained the following blocks (Table 2):

1. Estimation of students' knowledge of 12 chemical eponyms studied in both the US and Belarus: Schrödinger, Arrhenius, and Nernst equations; Pauli, Le Châtelier, and Heisenberg principles; Hess, Henry, Raoult, and Charles laws; Rydberg and Planck constants:

- question 1 aimed to estimate the knowledge by association: which chemical notions are associated with which chemists at a mere recognition level. It suggested dragging the 12 aforementioned scientists' names to four corresponding cells of the table: equations, principles, laws, and constants;

- questions 2-13 aimed to estimate the knowledge by content: which chemists are associated with the same 12 equations, principles, laws, or constants described without explicitly naming eponyms. It suggested choosing the author from the list of four.

2. Estimation of students'visual knowledge of 6 chemists (questions 14-19) studied in both the US and Belarus. Students were asked to recognize chemists on the portraits borrowed from the textbooks UO and BSU students used (Curie, Dalton, Gibbs, Lavoisier, Lewis, and Mendeleev). It suggested choosing the name from the list of four. 
ISSN 1648-3898/Print/ FIR HUMANIZATION AND HISTORICISM: HOW WELL UNIVERSITY STUDENTS KNOW AND

3. Estimation of students' perception and views of eponyms:

- questions 20-23 aimed to estimate, on examples of students' most and least known eponyms, whether they only recall the chemical content of or go reflexive and recall the author, too, recall his/her image, imagine communication with him/her;

- question 24 asked to estimate on a 5-point (1 - strongly disagree, 2 - disagree, 3 - neither agree nor disagree, 4 - agree, 5 - strongly agree) Likert scale how student likes eponyms in chemistry and how they are needed in and help study chemistry.

4. Collection of students' personal data (questions 25-27): gender ( $M, F$ ), major (chemistry, non-chemistry science, social science), and grade for the course (expected or earned).

The questionnaire for BSU students was translated into Russian and adopted to match the reality in this country (Slabin, 2014b):

- in question 11 asking to name the author of one of gas laws $(\mathrm{V} / \mathrm{T}=\mathrm{const})$, the correct option was replaced by "Gay-Lussac" - by this name Charles law (US) goes in Belarus;

- in question 14 asking to recognize the chemist (Curie), the wrong option "Aufbau" was replaced by "Franklin" - the aufbau principle of filling energy levels in the atom is not referred to as such in Belarusian chemical tradition;

- in question 26 asking to indicate major, the options were changed for "chemistry-teaching", "chemistryscientific", and "non-chemistry science".

In each of the two consecutive years, the link to the questionnaire was sent out via email to students during the final week of the course, after they had received their grades. The students had one week to respond the questionnaire. In administering the survey, ethical issues associated with online educational research (Roberts \& Allen, 2015) were considered and the necessary requirements were met: 1 ) the students' participation was voluntary; 2 ) the students had been informed about the risks (minimal), benefits, and facts before they made the decision to participate; 3) wording and ordering in the questionnaire strived to eliminate any potential for bias; 4) precautions were taken to ensure the privacy and confidentiality of the participants and their responses - the participation was anonymous; 5) the potential harm of the survey was minimized not to mislead, humiliate, or embarrass the participants or cause them psychological discomfort.

Table 2. The questionnaire.

\begin{tabular}{|c|c|}
\hline $\mathbf{N}$ & Item $^{a}$ \\
\hline 1 & $\begin{array}{l}\text { Drag the chemists' names to the appropriate boxes. } \\
\text { - equation: [Schrödinger, Arrhenius, Nernst] } \\
\text { - principle: [Pauli, Le Châtelier, Heisenberg] } \\
\text { - law: [Hess, Henry, Raoult, Charles] } \\
\text { - constant: [Rydberg, Planck] }\end{array}$ \\
\hline 2 & What scientist proposed it? $E \Psi=H \Psi$ [Schrödinger] \\
\hline 3 & $\begin{array}{l}\text { What scientist formulated it? "No two electrons in the same atom can have the same four quantum numbers" } \\
\text { [Pauli] }\end{array}$ \\
\hline 4 & What scientist introduced it? $R=1.096776 \times 10^{7} \mathrm{~m}$ [Rydberg] \\
\hline 5 & $\begin{array}{l}\text { What scientist formulated it? "When a chemical system in equilibrium is disturbed, it reattains equilibrium by un- } \\
\text { dergoing a net reaction that reduces the effect of the disturbance" [Le Châtelier] }\end{array}$ \\
\hline 6 & What scientist invented it? $k=A \times e^{-E a /(R T)}[$ Arrhenius $]$ \\
\hline 7 & What scientist established it? $\Delta H=\Sigma\left(\Delta H_{f, \text { products }}^{\circ}\right)-\Sigma\left(\Delta H_{f, \text { reactants }}^{\circ}\right)$ [Hess] \\
\hline 8 & $\begin{array}{l}\text { What scientist established it? "The solubility of a gas is directly proportional to the partial pressure of the gas } \\
\text { above the solution" [Henry] }\end{array}$ \\
\hline 9 & What scientist established it? $E_{c e l l}=E_{c e l l}^{\circ}-R T / z F \times \ln Q[$ Nernst $]$ \\
\hline 10 & $\begin{array}{l}\text { What scientist established it? "The vapor pressure of solvent above the solution is proportional to the mole fraction } \\
\text { of the solvent" [Raoult] }\end{array}$ \\
\hline 11 & What scientist introduced it? $h=6.62606957(29) \times 10^{-34} \mathrm{~J} \cdot s$ [Planck] \\
\hline 12 & $\begin{array}{l}\text { What scientist established it? "It is impossible to know the exact position and momentum of a particle simultane- } \\
\text { ously" [Heisenberg] }\end{array}$ \\
\hline
\end{tabular}




\begin{tabular}{|c|c|}
\hline N & Item ${ }^{a}$ \\
\hline 13 & $\begin{array}{l}\text { What scientist established it? "At constant pressure, the volume occupied by a fixed amount of gas is directly } \\
\text { proportional to its absolute (Kelvin) temperature" [Charles] }\end{array}$ \\
\hline $14-19$ & Who is this chemist? \\
\hline [Curie] & [Mendeleev] \\
\hline 20 & $\begin{array}{l}\text { From the list, pick a notion named after the scientist whose image and/or biography you know the most. [lf you do not know anybody, } \\
\text { click the Next arrow.] } \\
\text { Schrodinger equation, Planck constant, Gibbs energy, Pauli principle, Heisenberg principle, Dalton theory, Rydberg constant, } \\
\text { Charles law, Coulomb law, Le Châtelier principle, Lewis acid, Henry law, Arrhenius equation, Avogadro number, Boltzmann constant, } \\
\text { Hess law, London force, Brønsted - Lowry theory, Graham law, de Broglie wavelength, Clausius - Clapeyron equation, Nernst equa- } \\
\text { tion, van der Waals radius, Henderson - Hasselbalch equation, Raoult law, van't Hoff factor }\end{array}$ \\
\hline 21 & How do you react when you happen to hear the named notion you chose? \\
\hline & $\begin{array}{ll}\text { [I only get chemical content; } & \text { I imagine how this chemist would talk to me; } \\
\text { I recall that such chemist lived; } & \text { I recall how this chemist looks like; } \\
\text { I imagine how I would talk to this chemist; } & \text { I recall this chemist's biography] }\end{array}$ \\
\hline 22 & $\begin{array}{l}\text { From the following list, pick a notion named after the scientist whose image and/or biography you know the least. [lf you do not know } \\
\text { anybody, click the Next arrow.] } \\
\text { (the same list as in question 20) }\end{array}$ \\
\hline 23 & How do you react when you happen to hear the named notion you chose? \\
\hline & $\begin{array}{ll}\text { [I only get chemical content; } & \text { I imagine how this chemist would talk to me; } \\
\text { I recall that such chemist lived; } & \text { I recall how this chemist looks like; } \\
\text { I imagine how I would talk to this chemist; } & \text { I recall this chemist's biography] }\end{array}$ \\
\hline 24 & $\begin{array}{l}\text { To what extent do you agree with the statements below about named notions in Chemistry like those you were asked about? } \\
\text { - I like them. } \\
\text { [strongly disagree, disagree, neither agree nor disagree, agree, strongly agree] } \\
\text { - They are needed in Chemistry. } \\
\text { [strongly disagree, disagree, neither agree nor disagree, agree, strongly agree] } \\
\text { - They help study Chemistry. } \\
\text { [strongly disagree, disagree, neither agree nor disagree, agree, strongly agree] }\end{array}$ \\
\hline 25 & What is your gender? [M, F] \\
\hline 26 & $\begin{array}{l}\text { What is your major? } \\
\text { [chemistry, sciences but not chemistry, social sciences, humanities, other] }\end{array}$ \\
\hline 27 & $\begin{array}{l}\text { What is your grade for the class (earned or planned)? } \\
{[(A-, A, A+) ;(B-, B, B+) ;(C-, C, C+) ;(D-, D, D+) ; F]}\end{array}$ \\
\hline
\end{tabular}

Note. The questions are followed by the answers given in brackets.

\section{Websites of Student Reviews}

Because history of science is a natural discourse eponyms occur in, a preliminary study of how students envision history of science and, eventually, related eponyms, was undertaken. International anonymous student reviews of their instructors (teachers) were searched for on RateMyProfessors.com and RateMyTeachers.com by queries "eponym", "name", "scientist", "history of discovery", and "history of science" and then analyzed. 
ISSN 1648-3898 /Print/ FOR HUMANIZATION AND HISTORICISM: HOW WELL UNIVERSITY STUDENTS KNOW AND

\section{Data Analysis}

$\mathrm{IBM}^{\circ} \mathrm{SPSS}^{\circ}$ (Statistical Package for Social Sciences, version 24 for Mac) was used to calculate both descriptive (means, variances, standard deviations and errors) and inferential (Mann-Whitney $(U)$ and Pearson $\left(\chi^{2}\right)$ coefficients and standard scores $(\mathrm{z})$ ) statistics of the survey results.

\section{Results of the Research}

The results obtained on the base of data collected via the survey and Internet search are presented according to the stated research goals.

\section{Students' Knowledge of Chemical Eponyms}

Table 3. Descriptive statistics of students' knowledge of the 12 selected chemical eponyms.

\begin{tabular}{|c|c|c|c|c|c|c|c|c|}
\hline $\begin{array}{l}\text { Groups by } \\
\text { university and course }\end{array}$ & Count & $\begin{array}{c}\text { Correct } \\
\text { matches } \\
\max \end{array}$ & $\begin{array}{l}\text { Correct } \\
\text { matches } \\
\text { actual }\end{array}$ & $\begin{array}{c}\text { Mean } \\
\text { correct } \\
\text { per } \\
\text { student }\end{array}$ & $\begin{array}{l}\text { Standard } \\
\text { deviation }\end{array}$ & $\begin{array}{c}\text { Standard } \\
\text { error of } \\
\text { mean }\end{array}$ & Variance & $\begin{array}{c}\% \text { Correct } \\
\text { matches }\end{array}$ \\
\hline \multicolumn{9}{|c|}{ Knowledge by association } \\
\hline $\begin{array}{l}\text { University of Oregon } \\
\text { - regular GenChem }\end{array}$ & 87 & 1044 & 684 & 5.70 & 2.334 & 0.250 & 5.449 & 65.5 \\
\hline - summer GenChem & 44 & 528 & 340 & 7.81 & 1.544 & 0.233 & 2.385 & 64.4 \\
\hline - regular OrgChem & 57 & 684 & 469 & 8.00 & 2.044 & 0.271 & 4.179 & 68.6 \\
\hline - summer OrgChem & 62 & 744 & 537 & 7.87 & 2.532 & 0.322 & 6.409 & 72.2 \\
\hline $\begin{array}{l}\text { Belarusian State University } \\
\text { - regular GenChem }\end{array}$ & 22 & 264 & 247 & 8.72 & 1.956 & 0.672 & 0.417 & 93.6 \\
\hline \multicolumn{9}{|c|}{ Knowledge by content } \\
\hline $\begin{array}{l}\text { University of Oregon } \\
\text { - regular GenChem }\end{array}$ & 87 & 1044 & 588 & 6.76 & 1.765 & 0.189 & 3.115 & 56.3 \\
\hline - summer GenChem & 44 & 528 & 296 & 6.73 & 2.161 & 0.326 & 4.668 & 56.1 \\
\hline - regular OrgChem & 57 & 684 & 378 & 6.63 & 1.829 & 0.242 & 3.344 & 55.3 \\
\hline - summer OrgChem & 62 & 744 & 418 & 6.74 & 2.769 & 0.352 & 7.670 & 56.2 \\
\hline $\begin{array}{l}\text { Belarusian State University } \\
\text { - regular GenChem }\end{array}$ & 22 & 264 & 204 & 9.27 & 1.386 & 0.296 & 1.922 & 77.3 \\
\hline
\end{tabular}

As follows from Table 3, BSU regular GenChem students exhibit higher scores in knowledge of eponyms by both association and content.

Mann-Whitney test revealed that:

1) in the knowledge of eponyms by association, UO regular GenChem students had significantly lower mean score than:

$$
\begin{array}{ll}
\text { UO summer GenChem: } & U=720, z \text {-score }=-5.81621 \text { at } p<.01 ; \\
\text { UO regular OrgChem: } & U=1224, z \text {-score }=-5.12688 \text { at } p<.05 ; \\
\text { UO summer OrgChem: } & U=1176, z \text {-score }=-5.85566 \text { at } p<.01 ; \\
\text { BSU regular GenChem: } & U=276, z \text {-score }=-5.1375 \text { at } p<.01 .
\end{array}
$$

2) in the knowledge of eponyms by content, BSU regular GenChem students had significantly higher mean score than:

$$
\begin{array}{ll}
\text { UO regular GenChem: } & U=255, z \text {-score }=-5.29604 \text { at } p<.01 ; \\
\text { UO summer GenChem: } & U=168, z \text {-score }=-4.29156 \text { at } p<.05 ; \\
\text { UO regular OrgChem: } & U=165, z \text {-score }=-5.04741 \text { at } p<.01 ; \\
\text { UO summer OrgChem: } & U=316, z \text {-score }=-3.71844 \text { at } p<.01 .
\end{array}
$$


Pearson chi-squared test revealed positive correlations between students' knowledge of eponyms by association and their major $\left(\chi^{2}=0.386\right.$ for UO regular GenChem at .01 level, $\chi^{2}=0.368$ for UO summer GenChem, $\chi^{2}=$ 0.253 for UO summer OrgChem and $\chi^{2}=0.437$ for BSU regular GenChem at .05 level) and grade $\left(\chi^{2}=0.363\right.$ for UO summer GenChem at .05 level and $\chi^{2}=0.621$ for BSU regular GenChem at .01 level). For calculations, majors "Social science", "Science" and "Chemistry" were assigned values 1, 2 and 3, resp.

Pearson chi-squared test also revealed positive correlations between students' knowledge of eponyms by content and their major $\left(\chi^{2}=0.261\right.$ for UO regular GenChem at .05 level and $\chi^{2}=0.340$ for UO summer OrgChem at .01 level).

The same data were used to find which chemical eponyms are more recognizable by association and by content (Figures 1 and 2).

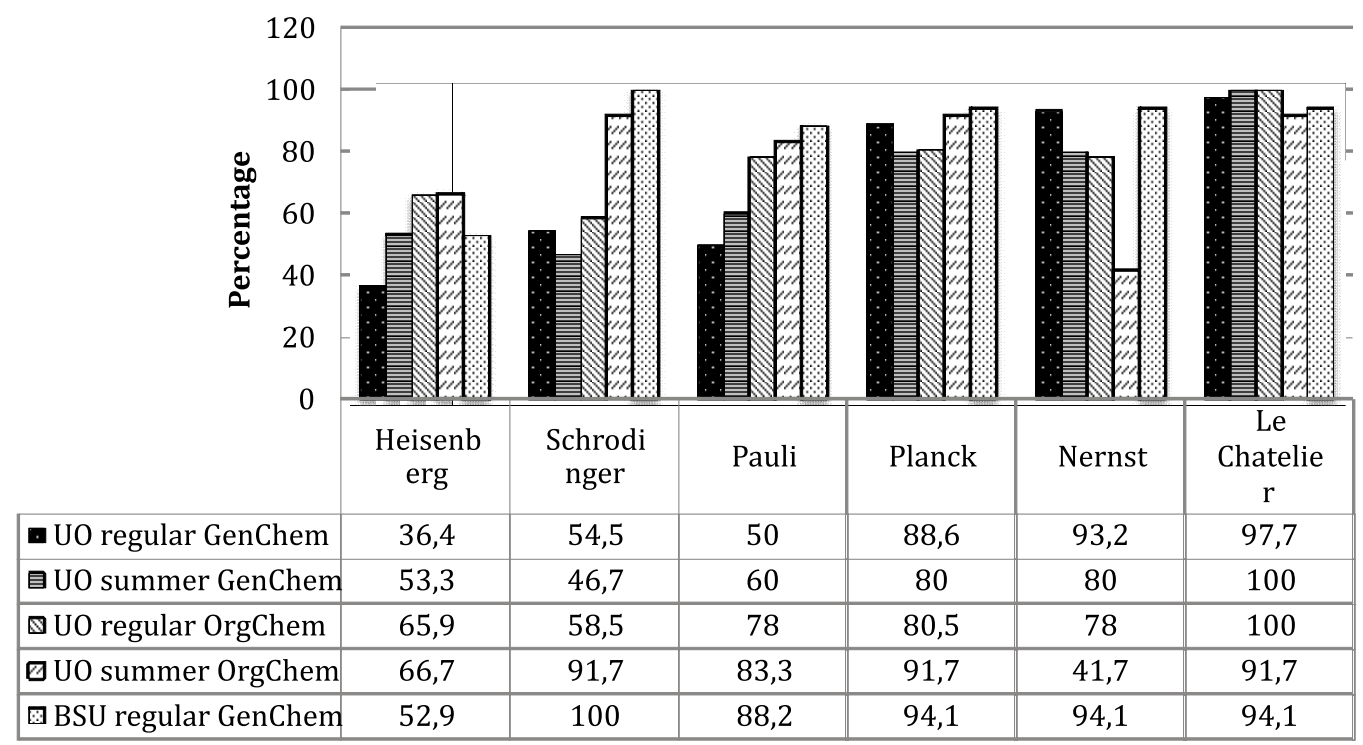

Figure 1: Recognition of chemical eponyms (6 of 12) by association in the five student groups.

Note. Words "equation", "principle", and "constant" are omitted.

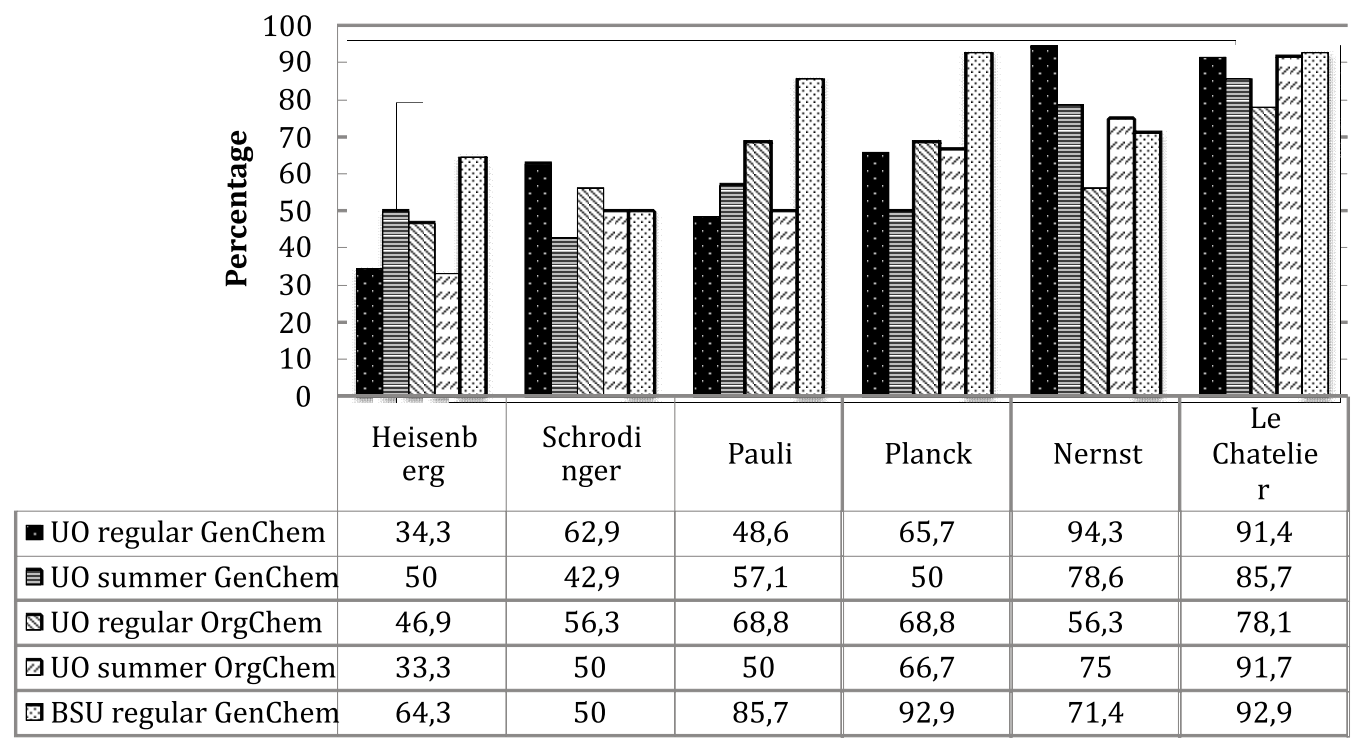

Figure 2: Recognition of chemical eponyms (6 of 12) by their content in the five student groups. Note. Words "equation", "principle", and "constant" are omitted. 
As seen from Figures 1 and 2: 1) some eponyms are recognized easier than others; 2) in recognition by association and by description the chosen six eponyms follow the same order; 3 ) percentages of recognition by association and by description are close but different in all the five student groups.

Table 4. Descriptive statistics of students' visual recognition of 6 selected chemists on portraits.

\begin{tabular}{|c|c|c|c|c|c|c|c|c|}
\hline $\begin{array}{l}\text { Groups by } \\
\text { university and course }\end{array}$ & Count & $\begin{array}{c}\text { Correct } \\
\text { matches } \\
\max \end{array}$ & $\begin{array}{c}\text { Correct } \\
\text { matches } \\
\text { actual }\end{array}$ & $\begin{array}{c}\text { Mean } \\
\text { correct } \\
\text { per } \\
\text { student }\end{array}$ & $\begin{array}{l}\text { Standard } \\
\text { deviation }\end{array}$ & $\begin{array}{c}\text { Standard } \\
\text { error of } \\
\text { mean }\end{array}$ & Variance & $\begin{array}{c}\% \text { Correct } \\
\text { matches }\end{array}$ \\
\hline $\begin{array}{l}\text { University of Oregon } \\
\text { - regular GenChem }\end{array}$ & 87 & 522 & 264 & 3.03 & 1.072 & 0.115 & 1.150 & 50.6 \\
\hline - summer GenChem & 44 & 264 & 112 & 2.55 & 1.247 & 0.188 & 1.556 & 42.4 \\
\hline - regular OrgChem & 57 & 342 & 153 & 2.68 & 0.869 & 0.115 & 0.756 & 44.7 \\
\hline - summer OrgChem & 62 & 372 & 172 & 2.77 & 1.247 & 0.158 & 1.555 & 46.2 \\
\hline $\begin{array}{l}\text { Belarusian State University } \\
\text { - regular GenChem }\end{array}$ & 22 & 132 & 92 & 4.18 & 0.958 & 0.204 & 0.918 & 69.7 \\
\hline
\end{tabular}

As follows from Table 4, BSU regular GenChem students exhibit higher scores in visual recognition of chemists on portraits.

Mann-Whitney test revealed that in visual recognition of the six chemists the students of

1) UO regular GenChem had significantly higher mean score than:

UO summer GenChem: $\quad U=1308$, $z$-score $=2.95075$ at $p<.01$;

UO regular OrgChem: $\quad U=2061, z$-score $=1.7076$ at $p<.05$.

2) UO regular OrgChem had higher mean score than:

UO summer OrgChem: $\quad U=984, \mathrm{z}$-score $=0.03216$ at $\mathrm{p}<.05$.

3) BSU regular GenChem had higher mean score than students in each of the four remaining groups:

$$
\begin{array}{ll}
\text { UO regular GenChem: } & U=441, \mathrm{z} \text {-score }=-4.1183 \text { at } \mathrm{p}<.01 ; \\
\text { UO summer GenChem: } & \mathrm{U}=180, \mathrm{z} \text {-score }=-4.12833 \text { at } \mathrm{p}<.05 ; \\
\text { UO regular OrgChem: } & \mathrm{U}=150, \mathrm{z} \text {-score }=-5.21146 \text { at } \mathrm{p}<.01 ; \\
\text { UO summer OrgChem: } & \mathrm{U}=254, \mathrm{z} \text {-score }=-4.34921 \text { at }<.01 .
\end{array}
$$

Pearson chi-squared test revealed positive correlation between students' visual recognition of chemists and their major $\left(\chi^{2}=0.401\right.$ for UO regular GenChem at .01 level and $\chi^{2}=0.308$ for UO summer OrgChem at .05 level)

The same data were used to find which chemists are more recognizable on their portraits (Figure 3).

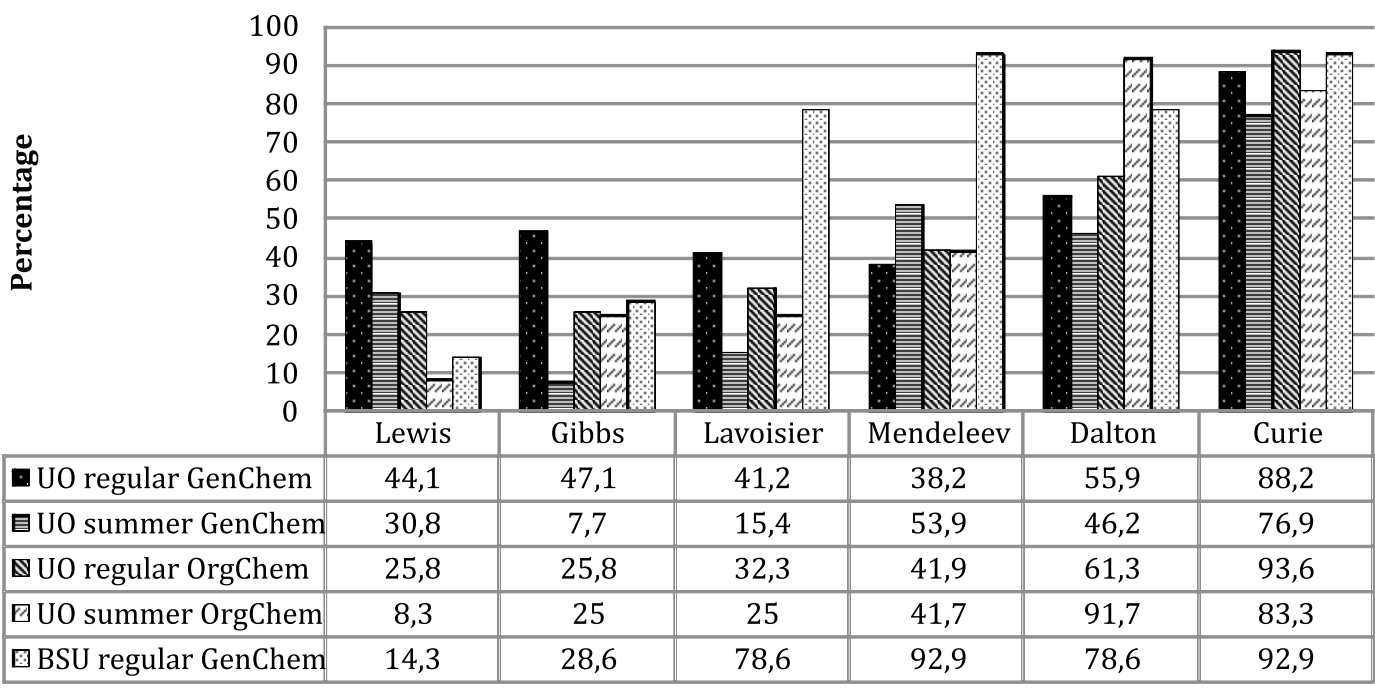

Figure 3: Visual recognition of the 6 selected chemists on portraits in the five student groups. 
FIR HUMANIZATION AND HISTIRICISM: HOW WELL UNIVERSITY STUDENTS KNOW AND

As seen from Figure 3, some chemists on portraits are recognized easier than others. Curie is recognized the most and Lewis the least in all the five student groups.

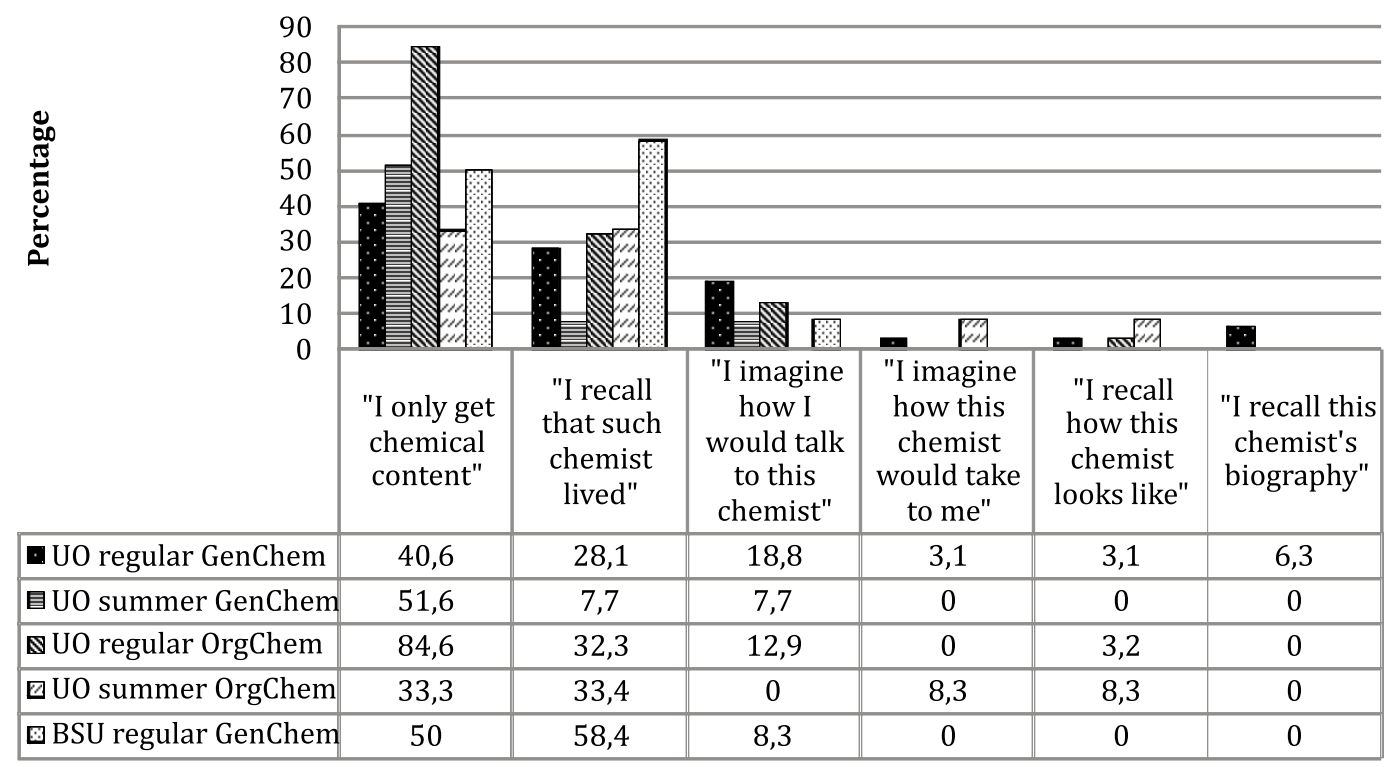

Figure 4: Audial perception of chemical eponyms in the five student groups.

As seen from Figure 4, most students in all groups tend to get only chemical content of eponyms (especially UO regular OrgChem) without recalling personalities behind them. The percentage of those recalling is lower and those imagining communication with chemists is even lower. While the answers to the four first questions allow to judge about students' reflection, the last two questions (image or biography) tell only about students' awareness.

\section{Students' Views of Chemical Eponyms}

Table 5 shows students' views of eponyms calculated as mean values on the 1-5 point Likert scale.

Table 5. Mean values of students' responses reflecting their view of eponyms.

\begin{tabular}{|c|c|c|c|c|c|c|c|}
\hline \multirow{2}{*}{$\begin{array}{l}\text { Groups by } \\
\text { university and course }\end{array}$} & \multirow{2}{*}{ Count } & \multicolumn{2}{|c|}{ "I like eponyms" } & \multicolumn{2}{|c|}{$\begin{array}{c}\text { "Eponyms are needed in } \\
\text { chemistry" }\end{array}$} & \multicolumn{2}{|c|}{$\begin{array}{l}\text { "Eponyms help study } \\
\text { chemistry" }\end{array}$} \\
\hline & & Mean & SD & Mean & SD & Mean & SD \\
\hline $\begin{array}{l}\text { University of Oregon } \\
\text { - regular GenChem }\end{array}$ & 87 & 3.21 & 0.966 & 3.79 & 0.966 & 3.66 & 0.998 \\
\hline - summer GenChem & 44 & 3.64 & 0.780 & 3.73 & 1.065 & 4.00 & 0.747 \\
\hline - regular OrgChem & 57 & 3.26 & 1.173 & 3.68 & 1.227 & 3.37 & 1.144 \\
\hline - summer OrgChem & 62 & 2.65 & 0.704 & 2.81 & 1.185 & 2.77 & 1.193 \\
\hline $\begin{array}{l}\text { Belarusian State University } \\
\text { - regular GenChem }\end{array}$ & 22 & 3.55 & 0.912 & 3.18 & 1.368 & 3.55 & 1.101 \\
\hline
\end{tabular}

As follows from Table 5, in aggregate, students are mostly unsure, with a slight shift to affirmative, about whether they like eponyms, whether eponyms are needed in chemistry and whether they help study chemistry. Mann-Whitney test revealed that:

1) summer general chemistry students at UO "like eponyms" more than UO regular GenChem: $\quad U=1374, \mathrm{z}$-score $=-2.62911$ at $\mathrm{p}<.01$; 
ISSN 1648-3898/Print/ FOR HUMANIZATION AND HISTORICISM: HOW WELL UNIVERSITY STUDENTS KNOW AND

UO summer OrgChem: $\quad U=488, z-s c o r e=-5.61349$ at $p<.01$.

2) UO summer OrgChem students "like eponyms" less than

UO regular GenChem: $\quad U=1665, \mathrm{z}$-score $=3.97245$ at $\mathrm{p}<.01$;

UO regular OrgChem: $\quad U=1017, z$-score $=-3.98693$ at $p<.05$;

BSU regular GenChem: $\quad U=314, z-s c o r e=-3.73879$ at $p<.05$.

3) UO summer OrgChem students believe that "eponyms are needed in chemistry" less than
UO regular GenChem:
UO summer OrgChem: $\quad U=1056, z$-score $=-3.77947$ at $p<.01$.

4) UO summer OrgChem students believe that "eponyms help study chemistry" more than each of the four remaining groups:

UO regular GenChem: $\quad U=1437, z$-score $=4.85051$ at $p<.05$;

UO summer GenChem: $\quad U=540, z$-score $=-5.28008$ at $p<.01$;

UO regular OrgChem: $\quad U=1233, z$-score $=-2.83793$ at $p<.01$;

BSU regular GenChem: $\quad U=426, z$-score $=-2.59935$ at $p<.01$.

5) UO summer GenChem students believe that "eponyms help study chemistry" more than UO regular OrgChem: $\quad U=876, z$-score $=-2.5855$ at $p<.01$.

Pearson chi-squared test revealed positive correlations between students' agreements with all the three statements in most groups:

- "I like eponyms"-"Eponyms are needed in chemistry": $\chi^{2}=0.532$ (UO regular GenChem), $\chi^{2}=0.468$ (UO regular OrgChem), $\chi^{2}=0.349$ (UO summer OrgChem), all at .01 level;

- "I like eponyms" - "Eponyms help study chemistry": $\chi^{2}=0.319$ (summer GenChem UO) at .05 level; $\chi^{2}$ $=0.364$ (UO regular GenChem), $\chi^{2}=0.485$ (UO regular OrgChem), $\chi^{2}=0.733$ (BSU regular GenChem) at .01 level;

- "Eponyms are needed in chemistry"-"Eponyms help study chemistry": $\chi^{2}=0.830$ (UO regular GenChem), $\chi^{2}=0.468$ (UO summer GenChem), $\chi^{2}=0.581$ (UO regular OrgChem), $\chi^{2}=0.711$ (UO summer OrgChem), $\chi^{2}=0.627$ (BSU regular GenChem), all at .01 level.

\section{Eponyms and History of Science in Student Reviews}

100 international students' reviews from RateMyProfessors.com and RateMyTeachers.com were selected and analyzed. Although no occurrence of "eponym(s)" was found, students mentioned "names of scientists". Both positive and negative feedback was provided for instructors and teachers of history of science and of other courses where they introduced elements of history of science. Table 6 provides characteristic examples of students'reviews.

Table 6. Students' reviews of their instructors where they mention eponyms and/or history of science.

History of science was a taken course:

"If you have any interest at all in philosophy or history of science, you will enjoy him";

"Fun class, history of science and technology is a class that should be taken by all who are interested in how society got to where it is";

"Doc is a moderately tough teacher, history of science has a lot more science than his other classes so if that is a strong suit it will help you in the class. I got an A with a minimal science background";

"He was versed in every topic of discussion. If you like the history of science and want to read Newton, Galileo, Aristotle, Heisenberg, Copernicus, and others, this is the course!";
History of science was incorporated in a non-history course:

"He is helpful, interesting, and engaging. My class was taught by him as well as three other professors, who alternated days of lecture. Although I am less interested in history of science that the other sections, I always find what he has to say interesting";

"I'm an art major but he made me love Geology. He made the concepts and even just the definitions and names of scientists very interesting and easy to remember";

"He is a very nice guy, and seems knowledgeable on the subject, however his tests are awful and only on the history of chemistry. The math that we do in class is never applied on the tests";

"Asks the most random questions on midterms like the history of chemistry instead of more important stuff that actually has a chance of being on the final"; 
History of science was a taken course:

"I recommend this class if you like history and science. It's more the history of science than anything else. Loved the class!";

"One of the best classes l've had. Professor has a passion for the history of science that is easily transferred to attentive students";

"The subject matter makes this course inherently difficult, so only take it if you are truly interested in the history of science!"

"He teaches the history of science, and knows little about history or science. Does not think outside of the box, but treats his selected texts like the Bible".
History of science was incorporated in a non-history course:

“Worst teacher and most unhelpful, does not care about students' grades. Over 15 percent of your entire microbiology grade depends on how you remember the names of scientists, most of which you learn on your own time";

"Do not take a class with him if you don't have to. He is more interested in the history of the material than the material itself";

"Awful teacher. Doesn't explain anything well. He's more concerned about the history of chemistry rather than the actual concepts";

"He cares more about the history of chemistry and comics than his actual lectures. If at all possible, I would not sign up for his class".

The following student's account shares a funny eponym story (fig Newtons are a sort of pastry):

"Brought in fig newtons for the first lecture but said we could only have some if we knew the name of the scientist the cookie was named after. Someone said "Isaac Newton" and he proceeded to say that was wrong and threw them away [sic]".

As follows from Table 6, in case of history of science as separate courses negative reviews relate to the instructor's qualification and teaching style. In case of non-history courses negative reviews relate to the fact of introducing eponyms and history of science to replace scientific information.

\section{Discussion}

On the one side, the obtained results reflect the current situation - how successfully the implementation of the principles of humanization and historicism at University of Oregon and Belarusian State University goes. On the other hand, they help to estimate the extent to which one can rely on eponyms in implementing the two principles.

\section{Knowledge of Eponyms}

The comparison of study results shows an essential difference in UO and BSU students major breakdown: whilst UO groups enrolled students majoring in chemistry, non-chemistry science and social science, BSU group was almost entirely chemistry (90.9\%) with the only adjustment of teaching chemistry vs. scientific/industrial chemistry. This factor suggests why BSU students were more motivated to study chemistry at all its fancy details and for this reason outscored their American peers in knowing eponyms by both association and content as well as in visual recognition of chemists on portraits. Furthermore, most BSU students (72.7\%) were pursuing teaching career and were expected to embrace the mentioned principles of humanization and historicism that emphasize eponyms (Republic of Belarus Ministry of Education, 2009). Better motivation to study eponyms resulted in better knowledge of them.

Likewise, UO summer general chemistry group that had three times more chemistry majors demonstrated higher score in knowledge of eponyms by association in comparison with UO regular general chemistry group. The correlation between major and performance was statistically confirmed, even though the major does not seem to be the only factor. Organic chemistry students with no or very modest percentage of chemistry majors, both regular and summer, showed higher scores in knowledge of eponyms by association than their general chemistry peers. This can be explained by the fact that organic chemistry is an advanced course taken by experienced and knowledgeable students who already studied general chemistry with eponyms.

As for the correlation between students' grades and knowledge of eponyms, one should conclude that it does not have a causal nature. More likely, it is a reflection of general performance in chemistry and knowledge of the subject that includes eponyms.

In general, the results indicate that students' scores of knowledge of eponyms by association are higher than those by association. Obviously, the former is an easier cognitive task: it is about recognition rather than retrieval of the associated concept. Interestingly, the order of students' knowledge of the six selected eponyms remains 
the same for both association and content (Figure 1). There can be numerous reasons for this phenomenon. E.g. Le Châtelier principle can be most recognizable simply because the chemist's name is associated solely with the principle he formulated and with nothing else. On the contrary, Heisenberg principle can be least recognizable because the eponym is also often referred to as "uncertainty principle." Another explanation can be easiness of readability or complex mechanisms of learning novel words with selective sharpening orthographic representations (Glezer, Kim, Rule, Jiang, \& Riesenhuber, 2015).

It is apparently the factor of majoring in chemistry that made BSU general chemistry students the champions in visual recognition of chemists on portraits. It outweighed the factor of their textbook (Tretyakov, 2004) that offered merely two images of chemists in - Lomonosov and Mendeleev. The organic chemistry textbook for UO (Bruice, 2014) was no better - about ten images of people (not only chemists; part of them being sculptures) including the author herself on 1290 pages. The general chemistry textbook for UO (Silberberg, 2012) did not provide images of any of the six chemists mentioned and was of no help for UO general chemistry students to outscore other surveyed UO groups in visual recognition of chemists.

Scarcity of chemists' portraits in textbooks suggests why no chemist on portraits was $100 \%$ recognized, and in case of Lewis the recognition did not even reach $50 \%$. Moreover, compared to the $6^{\text {th }}$ edition of the general chemistry textbook, its $4^{\text {th }}$ edition (Silberberg, 2006) had 25 (notably more) images of chemists including the six images the students were tested on. The situation is getting worse within the trend of decreasing incorporation of history of science in the teaching of science. There prevail "views that science history is no longer a legitimate subject in science education, that science history does not contribute to learning the technical aspects of science, or that it is difficult to fit into the topic loads of current science classes" (Rasmussen, Giunta, \& Tomchuk, 2008, p.79). While some educational activities include portraits of scientists and other famous people (Mesimumm, 2010; National Endowment for the Humanities, 2010; Russian State Herzen Pedagogical University, 2013), actual knowledge of them can be far from ideal. Manvelian (n.d.) shares a story of how she once asked a group of seniors of College of Physics and Technology at Russian Armenian University to name physicists in the portrait gallery but only two students were able to answer correctly.

Just like with eponyms themselves, there can be numerous factors defining which chemists are more recognizable on their portraits. It can be the style of portrait. Lewis was recognized the least by the students in our research presumably due to the style of his portrait: a chemist with a piece of glassware in hands (partly shadowed by it) - a stereotypic posture, about which Schummer (2009) argues that "before chemists assumed it [this posture] as their professional icon, the motif, originally representing uroscopy, was first an icon of medicine and then became a symbol of quackery and imposture" (p. 5). Curie turned out to be recognized the most, probably, because before entering the university students frequently saw her widely portrayed at high schools as a female scientist and a twice Nobel prize laureate. Mendeleev could be more recognizable because style of his portrait makes spectator's eyes follow, a phenomenon described long ago (Wollaston, 1824).

\section{Perception and Views of Eponyms}

The fact that after hearing an eponym, most students get only its chemical content seems natural. The need for related chemists' images and biographies seldom arises in the chemical laboratory; this knowledge is not necessarily practical. Moreover, normally it is not required for exams and quizzes. For this reason, UO regular organic chemistry students "only get chemical content" more than any other surveyed group. They have to learn plenty of named reactions, compounds, rules, effects, and laboratory glassware and neither time nor obligation to go beyond these eponyms. Because knowing chemists' images and biographies as well as readiness for more reflective perception of eponyms is desirable for teacher's profession, BSU students more often "recall that such chemists lived" and imagine their communication with them.

Possibly, UO summer general chemistry students "liked eponyms" more than their peers enrolled in summer organic chemistry for the following reason: eponyms in their course were not so abundant. Further, they "liked eponyms" and believed that "eponyms help study chemistry" more than regular general chemistry students because their course lasted only three months and students did not develop tiredness. In contrast, during the same three months UO summer organic chemistry students had to master an overwhelming number of eponyms - more and quicker than any other group. Sure enough, this group less than any other believed that "eponyms are needed in chemistry." So to the factor of major (high percentage of those who "liked eponyms" in BSU were chemistry/teaching majors) one should add the factor of study intensiveness (number of eponyms per study period). 
The results reflect a broader picture of today, where not only participants of this research but also scientists have various views of eponyms, their necessity in and ability to help study science. Medd (1953) passionately defends eponyms: "There is a dark movement gaining ground which teaches that the names of diseases should be descriptive and not eponymous... I like names that have a ring of history, names that recall those who were mighty physicians in palmier days... Let us condemn dull impersonal names, utility names in a utility age" (p. 1274). Anticipating the principle of humanization in education, Robertson (1972) describes an imagined dialog between an old physician and a young intern. He comments: "As a member of the old school, I have long worshipped the eponym as one of the last vestiges of humanism remaining in an increasingly numeralized and computerized society" (p. 1278). Advising replacement of eponyms with "more relevant nomenclature", Coleman (2006) nevertheless recognizes: "Do anatomy and histology students really need to know eponyms? The answer is probably still yes... Terminological expressions and concepts that have endured centuries are difficult to abandon... Perhaps the main reason is the convenience involved for both teachers and students" (p. 242).

Other researchers are not so positive. Kishore (2000) reports his experience studying eponyms for medical students and remarks: “Eponyms do serve a useful function in some instances, but in clinical practice most trainees would prefer not to use them because they are confusing... For reasons of accuracy in communication it is time to move towards descriptions and classifications which are relevant to treatment, prognosis and research" (p. 426). Wallisch (as cited in Collier, 2012) lists disadvantages of eponyms but at the same time he does not suggest a good alternative:"Eponyms are not descriptive. Many are not universal... They can be ambiguous or cumbersome... Science needs a precise language that reflects the relationship between the underlying principles that governs nature, and naming scientific discoveries after people in no way furthers our understanding of the physical world" (p. 1879).

\section{Eponyms and History of Science}

The research findings on the Internet, anonymous students' reviews of their instructors mentioning eponyms and history of science, did not include data about their major. However, to explain the observed difference in perception of history of science when it goes as a separate course vs. its elements incorporated in a non-history course, one can suppose that major here plays an important role. Students majoring in history more often take history of science than those majoring in science. But here a problem arises: history students have to know some science enough to understand inventions and discoveries. Busotti (2015) from his teaching experience testifies that "there was a big problem: most of the students did not have a sufficient knowledge of the mathematics used by Ptolemy and Copernicus... Therefore, I am convinced that history of astronomy is a particularly suitable subject for a history of science course conceived for students who have historical and philosophical interests, which go beyond science..." Based on students' Internet reviews, however, one can suppose a fairly modest percentage of those majoring in science and having "historical and philosophical interests".

Just like among students, the perception of eponyms as a part of history of science differs among scientists, too. Rasmussen et al. (2008) sound positive and list eight important roles history of science plays in science education including two mentioned in educational standards: humanization of the subject matter of science and contribution to understanding the nature of science. Speaking of eponyms in the aspect of humanization, Seker (2012) considers them on two levels: scientist as a person and image of scientist. Govindarajan et al. (1993) state that "scientific eponymy particularly harbors a rich storehouse of anecdotes that could motivate the young learner of science" (p. 340) and puts up a two-step technology of studying eponyms: on the first step teacher searches anecdotal records of eponyms and recall them to students, on the second step students document each anecdote using a special format and a hands-on library.

On the contrary, Bent (1977) somewhat sarcastically provides "spectrum of uses" of history in teaching chemistry: "A sense of history is useless in taking the GRE exam, seldom useful in teaching engineering students, sometimes useful in teaching chemistry majors, frequently useful in teaching liberal arts students, always useful in writing texts" (p. 462).

Regardless of how high scientists value the role of history of science in teaching science, they all complain the lack of time. Pepper (1949) admits that "however sympathetic the teacher may be, he seldom finds the time to discuss new terms encountered, or to explain the origin which so often adds color, significance, and historical interest not only to the word but to the subject" (Foreword). Govindarajan et al. (1993) confirms that even though the classroom teacher of science often finds eponyms to be of interest to students, the time involved in researching for the information may be both demanding and taxing on the teacher. Reviewing historical vignettes for hooking 
students' attention, Clary \&Wandersee (2015) point: "Not only must the history be interesting, but it must also align with the required... content teachers are mandated to teach... and require minimal... classroom time" (p. 311).

Whereas didactic potential of eponyms (as a shorthand for chemical content) is obvious and utilized anyway, their axiological potential is utilized only if teacher purposefully does it. Francl (2012) argues that "eponyms work as historical nanolessons only when students are curious enough to dig out the related biographies (or at least read the sidebars in their textbooks), or when staff are scrupulous in drawing attention to them" (p. 957). In turn, how instructor's intention to utilize the axiological potential will be met, depends on students' major (history-related or science-only).

\section{Conclusions}

It was found on example of University of Oregon and Belarusian State University that students exhibit better knowledge of chemical eponyms by association than by their content. Students'knowledge and views of eponyms are defined mostly by major: students majoring in teaching chemistry exhibit higher knowledge and express more positive views of eponyms than those majoring in non-teaching, non-chemistry and especially non-science. While students majoring in science seldom exhibit positive views of eponyms and history of science incorporated into science courses, students majoring in history appreciate history of science in history courses. Major also defines students' performance to visually recognize chemists on portraits in their study courses. Other factors include students' learning experience: more experienced students exhibit better knowledge; study intensiveness: students' in more intensive (time wise and eponym wise) courses exhibit less positive views of eponyms.

While didactic potential of eponyms is utilized anyway, its axiological potential is utilized depending on instructor's willingness and mastery, available time in auditorium and the above listed factors. For this reason, the axiological potential of eponyms in the light of principles of humanization and historicism manifested in national educational standards should not be exaggerated. Being convenient shorthand for the history of scientific discoveries, chemical eponyms nonetheless cannot be recommended as universal vehicles for these two principles.

\section{Acknowledgements}

The authors would like to thank Dr. Deborah Exton, Dr. Thomas Greenbowe and Dr. Gregory Williams, faculty of the University of Oregon Department of Chemistry and Biochemistry, for their assistance in administering the survey for this research.

\section{References}

Allchin, D. K. (2011). The gender of Boyle's law. Retrieved January 31, 2017, from University of Minnesota Web site: http://www. tc.umn.edu/ allch001/papers/boyle.pdf.

Ballentyne, D. W. G., Walker, L. E. Q., \& Marton, L. (1959). A dictionary of named effects and laws in chemistry, physics and mathematics. New York: The McMillan.

Bayer, A. E. (1987). The "Biglan model" and the smart messenger: A case study of eponym diffusion. Research in Higher Education, $26(2), 212-223$.

Beeching, C. L. (1989). A dictionary of eponyms ( $3^{\text {rd }}$ edition). London: Library Association Publishing.

Bent, H. A. (1977). Uses of history in teaching chemistry. Journal of Chemical Education, 54(8), 462-466.

Beolens, B., Watkins, M., \& Grayson, M. (2009). The eponym dictionary of mammals. John Hopkins University Press.

Bruice, P. Y. (2014). Organic chemistry (7 $7^{\text {th }}$ edition). Santa Barbara: Pearson.

Busotti, P. (2015). The teaching of history of science at the university: Some brief considerations. Journal of Baltic Science Education, 14 (5), 564-568.

Clary, R. M., \& Wandersee, J. H. (2015). The history of science in the science classroom: The past is the key to the future in science education. Earth Sciences History, 34 (2), 310-332.

Coleman, R. (2006). Eponyms in histology and histochemistry: Do they still serve a purpose, or should they be abandoned in favor of standard non-eponymous terminology? [Editorial]. Acta Histochemica, 108, 241-242.

Collier, R. (2012). Seeking a serious language for science. Canadian Medical Association Journal, 184(17), 1879.

Drahl, C. (2010). In names, history and legacy. Chemical and Engineering News, 88 (20), 31-33.

Dvulichanskaya, N. N. (2011). Didakticheskaya sistema formirovaniya professional'noi kompetentnosti studentov uchrezhdenii srednego special'nogo obrazovaniya $v$ processe estestvenno-nauchnoi podgotovki [Didactic system of forming professional competence in students of secondary vocational educational institutions in the natural science training] (Doctoral dissertation, Moscow Bauman State Technical University, 2011). Available from http://www.dissercat.com/content/ didakticheskayasistema-formirovaniya-professionalnoi-kompetentnosti- studentov-uchrezhdenii- 
Enersen, O. D. (1994). Whonamedit? A dictionary of medical eponyms. Retrieved January 31, 2017, from http://www.whonamedit. $\mathrm{com} /$.

Felts, J. H. (1999). Dietl's crisis: The rise and fall of medical eponyms. Perspectives in Biology and Medicine, 43 (1), 47.

Fernandez-Cano, A., \& Fernandez-Guerrero, I. M. (2003). Eponymy for research evaluation: Spanish cases from the educational field. Research Evaluation, 12 (3), 197-203.

Francl, M. (2012). Naming names. Nature Chemistry, 4(12), 956-957. Retrieved January 31, 2017, from http://www.nature.com/ nchem/journal/v4/n12/pdf/nchem.1508.pdf.

Funk, H. (2013). Kaempferol: A case study of what eponyms in chemical nomenclature can tell us. Archives of Natural History, 40 (1), 72-83.

Glezer, L. S., Kim, J., Rule, J., Jiang, X., and Riesenhuber, M. (2015). Adding words to the brain's visual dictionary: Novel word learning selectively sharpens orthographic representations in the VWFA. The Journal of Neuroscience, 35 (12), 4965-4972.

Govindarajan, G., \& Rao, S. S. (1993). Scientific history and the educational significance of eponyms in science and medical instruction. Journal of Instructional Psychology, 20(4), 340-343.

Haabersti Russian Gymnasium. (2010). Poriadok provedeniya interaktivnoi igry "Mesimumm" [The scenario of «Bee» interactive game]. Retrieved January 31, 2017, from http://www.hvg.tln.edu.ee/ mesimumm/ru/2010-2011-2.

Hassner, A., \& Stumer, C. (2002). Organic syntheses based on name reactions. Amsterdam: Elsevier.

Kanne, J. P., Rohrmann, C. A., \& Lichtenstein, J. E. (2006). Eponyms in radiology of the digestive tract: Historical perspectives and imaging appearances. Radiographics, 26 (1). Retrieved January 31, 2017, from http://pubs.rsna.org/doi/abs/10.1148/ rg.261055084.

Kishore, M., Khashaba, A., Dikanara Babu, E., Harries, W. J., Blewitt, N. (2000). Eponyms - are they relevant? Injury, 31 (6), $425-426$.

Koehler, P. J., Bruyn, G. W., \& Pearce, J. M. S. (Eds.). (2001). Neurological Eponyms. Oxford University Press.

Lamanauskas, V. (2015). Natural science and technology education:Values component [Editorial]. Journal of Baltic Science Education, $14(6), 704-705$.

Lawson, E. D. (1984). Personal names: 100 years of social science contributions. Names, 32 (1), 45-73.

Manser, M. H. (1988). Dictionary of eponyms. London: Sphere.

Manvelian, A. (n.d.). Kto takie? [Who are they?] Retrieved January 25, 2017, from http://www.rau.am/gazeta_old/?v=41\&r=289.

Medd, W. E. (1953). Eponyms [Correspondence]. British Medical Journal, 2 (4848), 1274.

National Committee on Science Education Standards and Assessment, National Research Council. (1996). National Science Education Standards. Washington, D. C.: The National Academies Press. Available from http://www.nap.edu/catalog/4962/ national-science-education-standards.

National Endowment for the Humanities. (2010, September 27). What presidential portraits reveal. Retrieved January 31, 2017, from https://edsitement.neh.gov/lesson-plan/what-presidential-portraits-reveal.

NGSS Lead States. (2013). Next generation science standards: For states, by states. (Vols. 1-2). Washington, D. C.: The National Academies Press.

Paluzzi, J. (December 4, 2010). Eponyms app offers a great free medical database reference tool for Android phones. Retrieved January 31, 2017, from http://www.imedicalapps.com/2010/12/ eponym-free-android-medical-app-review/\#.

Papeo, G., \& Pulici, M. (2013). Italian chemists' contributions to named reactions in organic synthesis: An historical perspective. Molecules, 18, 10870-10900.

Pepper, P. O. H. (1949). Medical etymology: The history and derivation of medical terms for students of medicine, dentistry, and nursing. PA, Philadelphia: W. B. Saunders.

Rasmussen, S. C., Giunta, C., \& Tomchuk, M. R. (2008). Content standards for the history and nature of science. In S.L. Bretz (Ed.), Chemistry in the National Science Education Standards: Models for Meaningful Learning in the High School Chemistry Classroom (pp.79-86). Washington, D.C.: American Chemical Society, Education Division.

Rate my professors: review teachers and professors, school reviews, college campus ratings. Retrieved January 31, 2017, from http://www.ratemyprofessors.com.

Rate my teachers: helping students, parents and teachers make informed decisions within education. Retrieved January 31 , 2017, from http://www.ratemyteachers.com.

Republic of Belarus Ministry of Education, order 32 (May 29, 2009). Obrazovatel'nyj standart uchebnogo predmeta "himija" (7-11 klassy) [Educational standard for the study subject of chemistry (grades 7-11)]. Retrieved January 31, 2017, from http:// edu.gov.by/doc-3853.

Republic of Belarus Ministry of Education, order 675 (May 29, 2009). Koncepcija uchebnogo predmeta "himija" [Conception of the school subject of chemistry]. Retrieved January 31, 2017 from http://adu.by/wp-content/uploads/2014/umodos/kup/ Koncept_himia.doc.

Roberts, L. D., \& Allen, P. J. (2015). Exploring ethical issues associated with using online surveys in educational research. Educational Research and Evaluation, 21(2), 95-108. Retrieved January 31, 2017, from http://dx.doi.org/10.1080/13803611.2015.1024421.

Robertson, M. G. (1972). Fame is the spur the clear eponym doth raise [Letter to the editor]. The Journal of the American Medical Association, 221 (11), 1278.

Ruiz, R. (2006, September 12). History and evolution of the scientific thought. Retrieved January 31, 2017, from http://www.monografias.com/trabajos-pdf/scientific-thought/scientific-thought.pdf.

Russkij gosudarstvennyj pedagogicheskij universitet imeni Herzena [Russian State Herzen Pedagogical University] (2013, May 17). Retrieved January 31, 2017, from https://www.herzen.spb.ru/ main/structure/fukultets/him/1401474781/1401475178/.

Sala, S., De Renzi, S. (2002). Boycott the Chauvinistic eponyms. Cortex, 38, 87-92. 
ISSN 1648-3898/Print/ FOR HUMANIZATION AND HISTORICISM: HOW WELL UNIVERSITY STUDENTS KNOW AND

Schummer, J., \& Spector, T. I. (2007). The visual image of chemistry: Perspectives from the history of art and science. HYLE - International Journal for Philosophy of Chemistry, 13, 3-41.

Seker, H. (2012). The instructional model for using history of science. Educational Sciences: Theory and Practice, 12 (2), 1152-1158. Silberberg, M. S. (2006). Chemistry: the molecular nature of matter and change (4th ed.). New York: McGraw-Hill.

Silberberg, M. S. (2012). Chemistry: the molecular nature of matter and change ( $6^{\text {th }}$ ed.). New York: McGraw-Hill.

Slabin, U. K. (1995). Prablemy asimiliatsyi prozvishchau zamiezhnyh vuchonyh-himikau u bielaruskai movie [Problems of transcription of foreign chemists' names in Belarusian language]. In Prablemy bielaruskai navukovai terminalohii (pp. 225-233). Minsk: Tavarystva Bielaruskai Movy.

Slabin, U. (2014). Questionnaire for studying how well students know chemical eponyms and what they think of them. Retrieved January 31, 2017, from https://oregon.qualtrics.com/SE/?SID=SV_6PUQWc0FtKnsbHv.

Slabin, U. (2014). Questionnaire for studying how well students know chemical eponyms and what they think of them. Retrieved January 31, 2017, from https://oregon.qualtrics.com/SE/?SID= SV_3ega5UED1iDyQPH [in Russian].

Snieckus, V. (2010). More on named reactions [Letter]. Chemical and Engineering News, (88), 32, 3.

Stepkina, E. F. (2011). Lingvisticheskie i kognitivnye osobennosti naimenovanij predmetov obuvi v anglijskom yazike, soderzhashchih eponim [Linguistic and cognitive peculiarities of English footwear names with an eponym in their structure]. Magister Dixit, 4 (12), 84-91.

Tretyakov, Yu. D. (Ed.). (2004). Neorchanicheskaja himija [Inorganic chemistry] (Vols. 1-3). Moscow: Academia.

Turnpenny, P.D., \& Pigott, R.W. (2001). Deletion 22q11 syndrome: acknowledging a lost eponym as we say farewell to an acronym [Letter to the editor]. Journal of Medical Genetics, 38, 271-273.

Vatsuro, K. V., Mishchenko, G. L. (1976). Imennye reakcii vorganicheskoj himii [Name reactions in organic chemistry]. Moscow: Himija. Wollaston, W. H. (1824). On the apparent direction of eyes in a portrait. Philosophical Transactions of the Royal Society of London, $114,247-256$.

Woywodt, A., Matteson, E., \& Whitworth, J. A. (2007). Should Eponyms Be Abandoned? British Medical Journal, 335(7617), $424-425$. Yee, A. (n.d.). Andrew Yee's medical eponym page. Retrieved January 31, 2017, from http://www.eponyms.net.

Zusne, L. (1987). Eponyms in psychology: A dictionary and biographical sourcebook. New York: Greenwood Press.

Uladzimir Slabin

Vasili Krasitski
PhD, Research Associate, Center for Advanced Technology in Education, College of Education, University of Oregon, 1244, Walnut Street, Suite 220

Eugene, OR 97403, United States of America.

E-mail: uslabin@uoregon.edu

Website: http://cate.uoregon.edu/index.php?option=com_content\& view $=$ article\&id $=10 \& \mid$ temid $=2$

$\mathrm{PhD}$, Associate Professor, Department of General Chemistry and Methodology of Chemistry Teaching, Belarusian State University, Republic of Belarus.

Website: http://www.bsu.by/ru/main.aspx?guid=26601 